\title{
Challenges of Spatial Planning in Poland in the Context of Global Climate Change-Selected Issues
}

\author{
Anna Katarzyna Andrzejewska (D)
}

Citation: Andrzejewska, A.K Challenges of Spatial Planning in Poland in the Context of Global Climate Change-Selected Issues. Buildings 2021, 11, 596. https:// doi.org/10.3390/buildings11120596

\section{Academic Editors:}

Emilio Bastidas-Arteaga and Baojie He

Received: 18 October 2021

Accepted: 19 November 2021

Published: 29 November 2021

Publisher's Note: MDPI stays neutral with regard to jurisdictional claims in published maps and institutional affiliations.

Copyright: (C) 2021 by the author. Licensee MDPI, Basel, Switzerland. This article is an open access article distributed under the terms and conditions of the Creative Commons Attribution (CC BY) license (https:// creativecommons.org/licenses/by/ $4.0 /)$.
Faculty of Architecture, Wroclaw University of Science and Technology, 27 Wybrzeze Wyspianskiego St., 50-370 Wroclaw, Poland; anna.andrzejewska@pwr.edu.pl

\begin{abstract}
Contemporary spatial planning struggles with many difficulties resulting from, inter alia, ongoing climate change. Ongoing environmental transformations pose many challenges for spatial policy across the entire globe. The aim of this paper is to analyse the effects of climate change on urban spaces in Poland and to answer the question of whether planning practice promotes adaptation to climate change and, if so, to what extent. This paper uses a descriptive and comparative research methodology to interpret planning provisions used in selected local spatial development plans in terms of the arrangements that aim to prevent the negative consequences of climate change. The subject of the analysis is the content of general and detailed plans defined in the texts of the examined resolutions of applicable local plans in the Lower Silesia and Greater Poland voivodeships. This study assessed the validity of applying specific planning provisions. This interpretation was determined on the basis of a review of the current provisions in the Polish law, literature on the subject, as well as the author's own professional experience in the field of spatial planning. The quantitative and qualitative research results are summarized in a table and also examined and described in detail. Examples of planning records that were used in the analysis of local plans are cited and compared. Finally, the adaptation challenges posed to spatial planning in Poland at the local level (communal) based on the obtained quantitative data on the issues were studied.
\end{abstract}

Keywords: adaptation; climate change; spatial planning

\section{Introduction}

Scientific studies carried out over many years indicate that both the social and economic development of many countries is threatened by the effects of climate change. Taking into account the scientific data provided by the Intergovernmental Panel on Climate Change (IPCC), which has already published five reports since 1990, it should be pointed out that the consequences of not heeding to environmental changes are increasingly destabilizing the spaces in which people live. The awareness of these consequences is crucial for making decisions on certain adaptation activities that could possibly apply on a large scale. The urbanization process undoubtedly proves that intensive development, mainly urban areas, has occurred. The term "development" has a decidedly meliorative overtone if we consider the gradual and complex process aimed at generating increasingly elaborate forms and, in some respects, also more perfect.

Among the significant sources of pro-ecological knowledge in Europe, two organizations act as important information exchange panels, both among decision-making bodies and society: the European Climate Adaptation Platform (ECAP) and the European Environment Agency (EEA). They represent the development and agreement adaptation policies on climate change at the European Union level. At the international level, two reports by the United Nations Environmental Programme (UNEP) and International Panel on Climate Change (IPCC) should be identified.

The results of many years of observations carried out in Europe and across the entire globe show that excessive emissions of greenhouse gases, mainly carbon dioxide, contribute to global warming. 
Global warming disrupts the Earth's energy balance on the basis of the so-called radiation forcing. The disruption in the climate system occurs as a result of the unlimited production of pollution as well as massive deforestation. This phenomenon has significantly progressed since the beginning of the industrial era (after 1850). Undoubtedly, anthropopressure affects the state of the spatial order and also creates irreversible environmental consequences [1].

Reports by the International Panel on Climate Change (IPCC) point to further widespread changes that have led to warming not only in the atmosphere, but the ocean as well. The result of ocean warming is a rise in the sea level as well as a reduction in Greenland's and the Antarctic's ice sheets (i.e., loss of mass and shrinkage). Progressive changes in the average annual temperature and precipitation have had an impact on many factors affecting the climate.

Based on the 1992 United Nations Framework Convention on Climate Change (UNFCCC or FCCC), rules for international cooperation regarding the reduction in greenhouse gas emissions into the air were defined. However, it was not until 1997 that the Kyoto Protocol introduced specific limits on these emissions [2]. Ultimately, all measures should aim to achieve environmental improvements first and foremost. Attempts to implement measures to adapt to the current extremely dynamic climate situation generate enormous costs, up to USD 100 billion annually in developing countries. It is important that all activities are undertaken at multiple levels by both the public-sector and private-sector, including within the framework of international agreements.

In fact, only since 2010 have strategic government documents referred to issues of climate change in a global context. Earlier studies of this type (even those from the beginning of the 21st century) were not concerned with climate issues. After the publication in 2013 of the European Commission's guidelines on the development of an adaptation strategy [3], strategic and sectoral documents began to take into account measures for adapting to climate change. Based on an analysis of the strategies of European cities, the need to include aspects of adaptation to climate change was clearly needed, as well as planning documents in the field of spatial development, i.e., at the municipal level [4].

The implementation of the spatial policy in Poland has been conducted on the basis of a statutory planning system in accordance with the provisions of the Urban Planning and Development Act of 27.03.2003 [5]. Proper spatial management determines the proper adjustment of the planned directions of development to the existing conditions. This is essential in creating a human living environment.

Article 2, Section 2 of the Urban Planning and Development Act of 27.03.2003 [5] refers to the definition of sustainable development, which is contained in the Environmental Protection Law Act of 27.04.2001 [6]. This concept defines the principles according to which the spatial policy should be implemented. Actions aimed at respecting the environment have a special place in this process. Barbara Szulczewska points out that, especially when planning the directions of urban development, as well as its transformations, landscape ecology in practical terms is of fundamental importance [7]. The definition "landscape ecology" has been used in Polish literature since the 1990s thanks to two researchers-Richling and Solon. The third - the last level of landscape ecology—deals with the implementation of possible actions based on environmental research [8]. Therefore, thoughtful planning activities are particularly important, especially in the context of the ongoing climate changes.

As indicated in the review "A Review of Urban Planning Research for Climate Change" published in 2017, the awareness of progressing climate change increased significantly, especially in 2005-2008. Climate issues began to be considered, taking into account the multidimensional approach to research on their effects and the possibilities of preventing a negative impact on the environment. From 2010, extensive activities in spatial management began on the basis of a strategic and adaptive approach to climate policy issues [9].

Currently, many scientific conferences (national and international) address climate issues, also in the context of the challenges posed to spatial planning to prevent the negative effects of climate change. It is worth mentioning the concept of the relatively 
new scientific field of "urban climatology", which focuses on the study of contemporary phenomena occurring in cities and, then, using appropriate urban planning tools, attempts are undertaken to implement certain solutions to improve the climate of these cities [10].

Thermal conditions in cities were written about in 1818 by Luke Howard, who pioneered the study of the city's climate [11]. Krzysztof Fortuniak points out that as early as the beginning of the 19th century, Polish researchers (Antoni Magier and Wojciech Jastrzębowski) noted that buildings, especially their character, undoubtedly have an impact on the local climate of cities and settlements, as evidenced for example by the temperature differences between those in the city centre and those in the suburbs [12]. This phenomenon has been called the "urban heat island" (UHI) and affects not only cities, but also every urbanized area outside of cities. At present, it is indicated that the UHI negatively affects both the inhabitants of urban environments and people and ecosystems located far from cities [13].

In turn, in 2019, Anita Bokwa carried out research work for the city of Krakow [14], where sodar data and satellite images were also used. Research conducted today, taking into account the changes having taken place over several decades, is of particular importance.

A team of Chinese scientists studied the variability of the UHI phenomenon in Shanghai from 1961 to 2017. It turned out that over these 56 years, the intensity of the UHI was $0.4{ }^{\circ} \mathrm{C}$ higher at night than during the day. Moreover, with regard to the designated stages of the differentiated temperature increase in the city area and taking into account the accelerating process of urbanization, it was indicated that the phenomenon of the "urban heat island" also spread to the suburbs and rural areas (especially after 2000) [15].

In turn, a team of Polish researchers performed an analysis of the intensity of the urban heat island in Warsaw that took place over the past ten years (2008-2017). The purpose of the analyses was to develop a statistical model. The research was based on the relationship between the air temperature observed in a ground station and the temperature of the city surface, which was detected remotely. The results were carried out for various locations in the city with a different type of land cover and taking into account the different degree of urbanization [16].

Additionally, today, the relationship between climate change and urbanized spaces has been indicated. The table (Table 1) below shows how climate change has progressed until now and what the predictions are for the scale of climate change over the next few decades within Poland's borders (from 1971-2090). This comparison shows the undoubted dependence of climate warming on the functioning of the environment on many levels. 
Table 1. Changes in climatic factors which have occurred in the area of Poland and which are likely to occur by 2090, on the basis of climate research data 1 .

\begin{tabular}{|c|c|c|c|c|c|c|c|c|c|}
\hline Climatic Factors & 1971-1980 & 1981-1990 & 1991-2000 & 2001-2010 & 2011-2020 & 2021-2030 & 2041-2050 & 2061-2070 & 2071-2090 \\
\hline Annual average temperature $\left({ }^{\circ} \mathrm{C}\right)$ & 7.4 & 7.8 & 8.0 & 8.2 & 8.6 & 8.7 & 9.3 & 10.1 & 10.6 \\
\hline Number of days with $\mathrm{T} \min <0^{\circ} \mathrm{C}$ & 114 & 107 & 101 & 102 & 97 & 97 & 82 & 72 & 65 \\
\hline Number of degree days, $\mathrm{T}<17^{\circ} \mathrm{C}$ & 3616 & 3488 & 3374 & 3234 & 3237 & 3236 & 3005 & 2803 & 2664 \\
\hline $\begin{array}{l}\text { Length of the growing season } \mathrm{T}>5^{\circ} \mathrm{C} \\
\text { (in days) }\end{array}$ & 199 & 205 & 210 & 217 & 223 & 224 & 237 & 247 & 253 \\
\hline $\begin{array}{l}\text { Longest dry period (precipitation }< \\
\qquad 1 \mathrm{~mm} \text { ) (in days) }\end{array}$ & 20 & 21 & 21 & 20 & 22 & 22 & 22 & 24 & 24 \\
\hline $\begin{array}{l}\text { Longest wet period (precipitation }> \\
\qquad 1 \mathrm{~mm})(\text { days })\end{array}$ & 9 & 9 & 9 & 9 & 9 & 9 & 9 & 9 & 9 \\
\hline Number of days with snow cover & 100 & 87 & 84 & 82 & 71 & 71 & 58 & 49 & 42 \\
\hline
\end{tabular}


The monographic study "Contemporary problems of Polish climate" edited by Longina Chojnacka-Ożga and Halina Lorenc is an interesting series of scientific and research publications, showed how many physical factors affect the Polish climate (i.e., temperature, insolation, radiation, hydrological conditions and rainfall) and what are the adaptation needs of urbanized areas [18]. The cited studies indicate the need for a reasonable use of the results of existing urban planning practices to improve the living conditions in the city. It is also extremely important to reduce the negative impact of developing cities on the environment.

This article focuses on the analysis of the provisions of selected local spatial development plans, based on literature sources and the author's several years of professional experience in the field of urban planning. This new research approach aims to identify the challenges for spatial planning in Poland in the context of the threats posed by ongoing climate change. In the course of the research, indications are sought which could further define the types of land use which could contribute to the improvement of the climate situation in Poland. Finally, the applied planning provisions are assessed in the context of adaptation possibilities to climate change. The subject of the research included planning studies for the area of Lower Silesian and Greater Poland voivodships. Out of over one hundred planning studies, about half are selected and subjected to further analyses. The selection method used is described later in the article.

\section{The Effects of Climate Change Important for Urban Spaces}

Systematically conducted scientific models (based on measurement data from satellites, so-called space probes, here, in the concept of the research, scientific ones) simulate the processes of climate change. On the basis of scientific models, it is assumed that further emissions of greenhouse gases will significantly contribute to the successive warming of the climate, the increase in average precipitation, the acidification and warming of the ocean as a result of the continuing rise in carbon dioxide concentrations, or the shrinking of the global ice cap and the spring snow cover in the Northern Hemisphere [19].

It is, therefore, necessary to indicate what effects current climate change is having on the functioning of urban spaces. On the other hand, spatial management also influences the aforementioned climate changes. This statement makes it clear that spatial planning is specifically challenged to prevent the possible consequences of climate change through well thought-out spatial policies. The concept of adaptation was, therefore, introduced as an activity, which should also refer to the adaptation of specific planning systems to an ever-changing reality, including the environment.

Therefore, planning policies should be conducted on the basis of an integrated environmental and climate policy. Developing a strategy at the local level is of fundamental importance and is extremely difficult, not only in Poland. Management at the commune level encounters numerous limitations, which result mainly from unadapted legal regulations as well as from the complexity of various issues—spatial, social, economic - that need to be reconciled [20].

A national policy of adaptation to climate change is being carried out in the territory of Poland. The KLIMADA project identifies 12 sectors for which specific "Urban Adaptation Plans" are undertaken in individual regions (voivodships) (the following sectors: construction, energy, water management, mining, forestry, urban areas, agriculture, biodiversity, coastal zones, transport, tourism and health) [21]. From the local planning point of view, the "urban areas" sector is essential, as it relies on activities that have a direct impact on spatial management at the local level. The local stage of the urban planning system in Poland includes activities aimed at developing local spatial development plans. It should be noted that the provisions of these plans should be consistent with overriding (master) documents-also in the field of environmental protection, as well as those relating to climate issues. Planning studies at the commune level constitutes a kind of practical interpretation of national and international regulations and management policies [20]. 
In the Polish legislation, the scope of the local spatial development plan is defined in the Ordinance of the Minister of Infrastructure on the required scope of a draft local spatial development plan of 26 August 2003 [22]. Issues related to the broadly understood environmental protection are one of the required provisions of the local draft plan, which are dictated by the above-mentioned regulation.

Katarzyna Szmigiel-Rawska notes that, from a legal point of view, actions under the adaptation policy to climate change in Poland are not the responsibility of local governments. However, they are responsible for all activities aimed at protecting the environment and the health of the population, which in fact indicates that, indirectly, local governments, nevertheless, have the competence to uphold the climate policy [23]. Urban expansion is one of the main factors having a negative influence on the environment. The scale of the expanding city of Shanghai over the last 32 years is presented below (the city's population has doubled since the 1980s from 12 million to 24 million, and the city's surface area has more than quadrupled from 119 square miles-around $308 \mathrm{~km}^{2}$ — to 503 square miles- $1302 \mathrm{~km}^{2}$; this is how insightful data provided by the Landsat 5 and 8 satellites are as part of NASA's Earth Observatory program).

Based on the intensity of transformations in this Chinese city, as well as in other developing cities, there has also been an increase in surface areas characterized by higher temperatures. These temperature differences occur during the day, but are most noticeable late in the evening, especially in winter. These differences were estimated as high as 10 degrees Celsius $\left({ }^{\circ} \mathrm{C}\right)$.

As indicated by Krzysztof Billewicz, issues related to the "urban heat island" also relate, to a large extent, to the issues of energy efficiency of buildings [24]. Assuming that some of the heat that is inside the buildings escapes to the outside through imperfections and leaks in the insulation, a rising ambient temperature would be noticed.

In analysing the effects of climate change in urban areas, it is also important to point out the problem of flooding, which, especially in recent decades, has caused a great deal of damage and, hence, losses, both public and private. The policy of counteracting floods is one of the most difficult and complex in the area of spatial management. Despite the fact that floodplains are areas of particular conflicts, they are often intended for development in local plans without any restrictions, which results in tragic consequences caused by floods [25]. Planning arrangements, based on the available flood hazard maps for the area of Poland [26], should introduce specific indications for possible restrictions on investments in flood risk areas.

Urban spaces are currently undergoing many changes also in terms of adapting certain spatial solutions to changing climatic conditions in order to prevent their negative effects. The method of investing has had a dramatic impact on the climate, as it causes its irreversible change. On the other side, the progressing climate change has had a destabilizing effect on spatial management, and, thus, on safety, health, and sometimes also human life.

\section{Research Method-Analysis of Planning Provisions in the Context of the Possibility of Preventing the Effects of Climate Changes}

\subsection{Justification for Undertaking Research Based on Legal Regulations in Poland}

It is not easy to analyse the planning provisions, which are applied in local spatial development plans, for their ability to care for environmental protection with emphasis on the prevention of possible effects of climate change for at least two reasons. First, progressing climate change has continuous, significant and often unpredictable effects. The second reason is the insufficient and unclear provisions of the Polish law regarding specific options of a local plan to encompass climate policy.

The task of local planning in Poland is primarily to determine the functions of the areas (the type of their destination), as well as the principles of their management and development. Ordinance of the Minister of Infrastructure on the required scope of a draft local spatial development plan of 26 August 2003 clearly indicates the obligation to also include in the local plan the requirements for the protection of spatial order, environment, 
nature and landscape, as well as cultural heritage. Therefore, while developing a local plan, there is space for addressing climate issues by defining arrangements aimed at respecting the natural environment.

As part of the prevention of the impact of the progressing climate change, planning at local level in Poland makes it possible to introduce guidelines which take into account the rational use, also with respect to agricultural land and forest areas. Determining the appropriate functions of an area based on the existing conditions, while taking into account the directions for its development, is both the most important and the most difficult task in spatial planning. An issue is also the arrangements for the development and management of investment areas. Buildings themselves are also of particular importance. Within their adaptation it is recommended to improve housing standards while taking into account climate change mitigation, in particular by reducing demand for electricity. Changing climatic conditions requires looking for alternative sources. Hydro, wind and photovoltaic energy present unlimited possibilities for the development of renewable energy, which can reduce the combustion of fossil fuels.

\subsection{The Area of Research}

Forty-two valid local spatial development plans located in the area of Lower Silesia and Greater Poland regions were selected for this study, out of more than one hundred plans. The approach consisted of selecting such studies which were characterized above all by a diversified functional and spatial programme. The target use of selected areas was built-up and undeveloped areas. Furthermore, they included areas where complex planning and development issues could be expected to occur. Such areas undoubtedly included those located along river valleys, located in a special neighbourhood of economic, production and industrial zones, within the reach of city centres, as well as agricultural and forest areas with a dense network of drainage ditches. Thus, planning provisions for areas with different functions were analysed in order to indicate whether the way in which the given area was developed, as well as the type of development and its nature, would cause various environmental effects that influence climate change.

The nature and intensity of development was also relevant to the study. Local plans located in both urban and rural areas were, therefore, selected. The scope of the study also considered the date of adoption of the analysed plans to include those introduced over the span of less than fifteen years (in the range of 2006-2021), that is, on the basis of the amended Urban Planning and Development Act of 27 March 2003 [5], and Ordinance of the Minister of Infrastructure on the required scope of a draft Local Spatial Development Plan [22].

\subsection{Research Course and Results}

According to the research, the first part of the planning arrangements-the general one-most often indicated the need for appropriate treatment of paved surfaces, i.e., parking lots, manoeuvring yards, or single parking spaces, as well as all access roads within the local plan. It recommended securing these pavements to prevent any oil or other chemical substances from seeping into the ground. It was also proposed that appropriate gradients be used to allow water to run off and, thus, also drain in a controlled manner. Action based on preventing oil derivatives from reaching the ground was identified as key. Another provision commonly included in local plans concerned the absolute protection of existing squares, roadside greenery around buildings and communication routes, as well as the obligation to minimize actions aimed at cutting down the existing trees (Figure 1). 


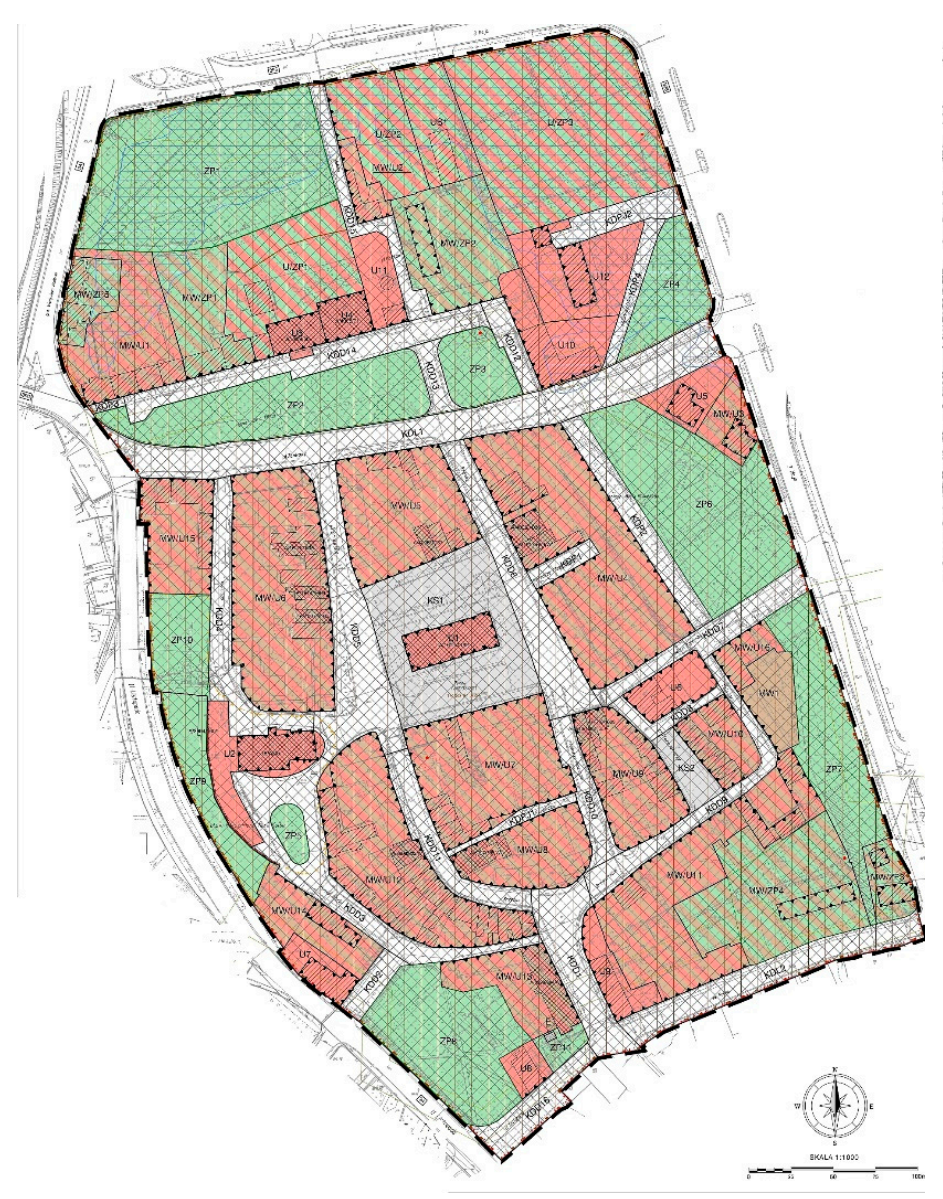

(a)

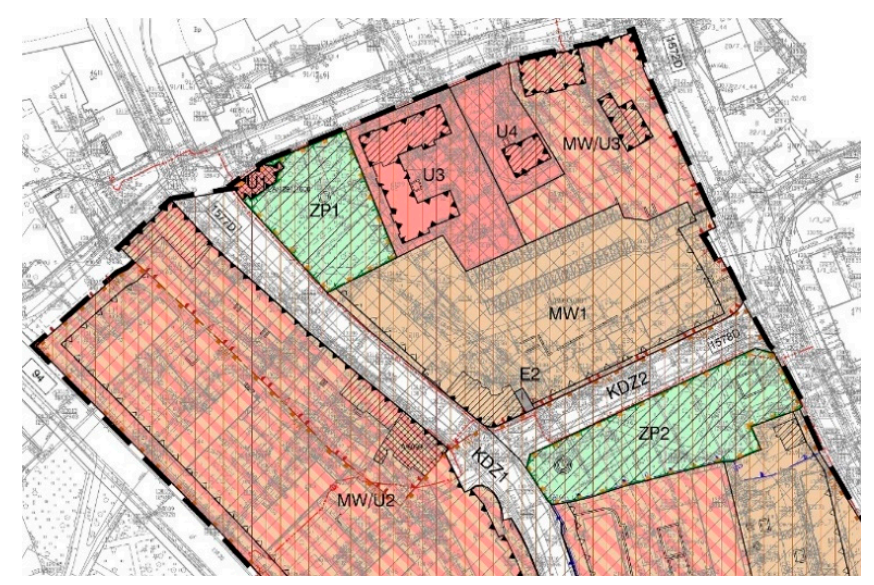

(b)

Figure 1. Arrangements of the local plan: $(\mathbf{a}, \mathbf{b})$ leaving the squares areas without the possibility of building development, maintaining the ring system of greenery in the city centre. The arrangements of the neighbouring areas include the function of greenery arranged for basic purpose, on par with the areas of multi-family housing and service buildings. Source: [27].

In addition, it was pointed out that all undeveloped and unpaved areas should be used for various forms of greenery. These provisions are essential to prevent/protect against the possible fragmentation of green spaces and allow for the formation of an appropriate climate in built-up areas. It is noted that compensation for biologically active areas should be sought to the greatest extent possible.

From the point of view of climate issues, the regulations applied in the detailed arrangements concerned the determination of values of particular urban planning coefficients for built-up areas. These concerned the size of the development area as well as the minimum ratio of biologically active surfaces. Depending on the type of site, as well as the location of the analysed site, these values varied the most-from the level of 10 to $90 \%$. For the process of adaptation to climate change, the values of the above-mentioned indicators are of less importance in themselves. It is essential to use appropriate proportions of these coefficients in relation to each other, while also determining the appropriate development intensity index.

Sometimes, the planning provisions of the analysed plans indicated the need of a share of a specific type of greenery in the adopted biologically active area, e.g., assuming that at least $70 \%$ of building plot surface of the area was to constitute a biologically active area, a minimum of $50 \%$ of this area was recommended to be designated for high greenery.

For functional areas (e.g., MW, MN, U, or P), but also for public roads of specific classes (e.g., KDZ, KDL, KDD), where a small minimum proportion of biologically active area (e.g., at a level of at least $10 \%$ of building plot surface) was indicated, the so-called 
green zones were sometimes additionally delimited, where detailed arrangements on the manner of their development were specified for each of them (Figure 2).

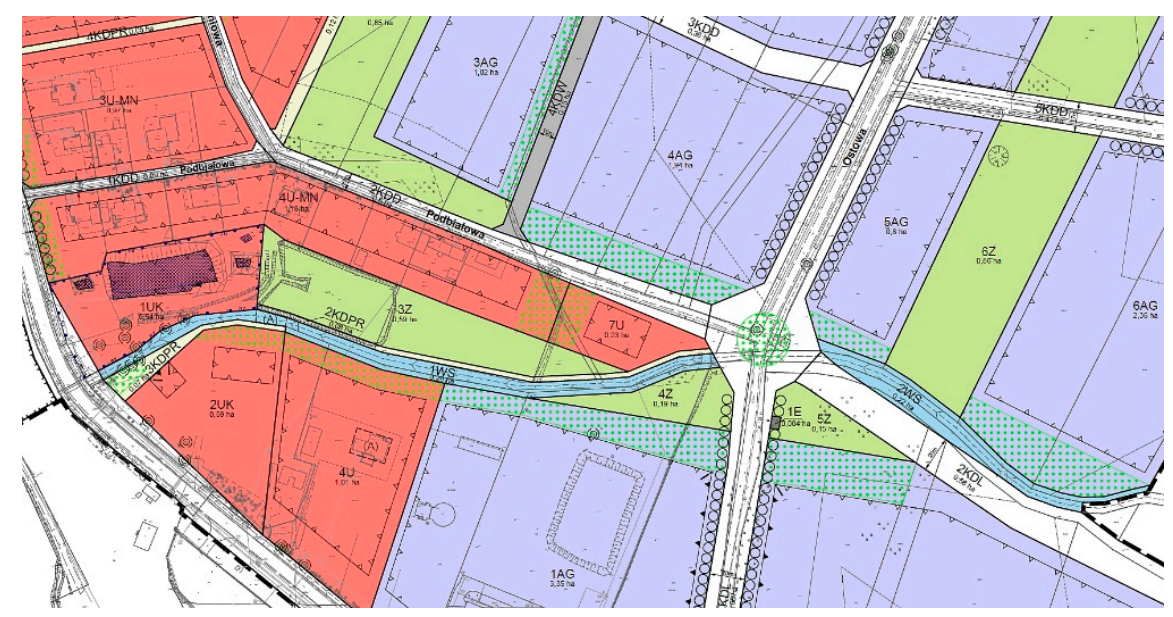

Figure 2. Green zones (marked with an openwork gradient) designated in the areas of functions: service (U), economic activity (AG) and public roads (KDL), except for strictly functionally defined green areas $(Z)$. Source: [28].

The most frequently used provisions include the prohibition of building development on at least $90 \%$ of the area of a given zone and the prohibition of parking spaces. Such indications make it possible to introduce additional guidelines, so that the ground surface, which is arranged in such a way as to ensure natural vegetation, constitutes, e.g., at least $75 \%$ of the area of each green zone, of which at least $40 \%$ should be covered with high greenery, assuming that, in addition, the protection of all trees applies.

Skilfully planned green infrastructure helps to eliminate the effects of advancing climate change on many levels. It increases the cooling effect of the surface and reduces the effects of the UHI phenomenon [29], cleans the air of pollutants, creates a specific microclimate or protects biodiversity. The possibility of modelling green and blue infrastructure networks, especially in urban areas, may contribute to noticeable changes in the perception of contemporary urbanized spaces [29].

Further provisions required of the regulation, which concern the principles of modernization, expansion and construction of communication systems and technical infrastructure, in most cases indicate the need to use the existing ones, and, in their absence, absolute implementation of new ones or expansion of the current technical infrastructure systems (i.e., water supply networks, sanitary sewage system, etc.). In contemporary cities, changes are clearly noticeable, especially in the communication infrastructure, which causes wideranging spatial changes [30]. In the context of the provisions for the discharge of rainwater and snowmelt, it was recommended to first remove oil-derived substances, as well as suspended solids, if present, from rainwater, before discharging it into the stormwater drainage system. Protection of land as well as groundwater is essential in the era of urbanization in times of climate change. An important provision found especially in urban areas is the one concerning the management of rainwater. The analysed local plans allowed for appropriate technical solutions to retain rainwater and snowmelt (e.g., from roofs and hardened areas) on the plot or within the property. Storage of rainwater contributes to the prevention of the effects of climate change, but is also an important element of the policy of minimizing the costs of sewage infrastructure. In 2005, the US city of Philadelphia saved USD7 billion as a result of raising fees for stormwater drainage from properties. The effect of the increase in costs had been to change the attitude of residents to small-scale retention. They even started covering their roofs with vegetation and planting trees by the pavements [31]. There had, therefore, been a significant increase in permeable surface area across the city. 
Among the planning provisions in the analysed selected plans, there were also such that referred to the limited possibilities of draining naturally occurring ditches. The permission only applied to intersections with streets, internal roads, footpaths, pedestrian and bicycle paths and also in other places that justified the development of the area for a public purpose.

For the purpose of stormwater drainage, some of the analysed plans included the obligation to use solutions consisting in the management of all or part of these waters at the place of precipitation, through economic use, evaporation, infiltration into the ground or direct retention. It should be noted that this provision is not just one of the possibilities for the described water management, but an obligation to be fulfilled, from the point of view of the planning provision relating to the specific areas identified in the local plan in question.

Within the framework of pro-ecological and pro-climate arrangements defined in development plans, it is worth pointing out that they are often based on all kinds of resolutions adopted on behalf of a given voivodship, commune or town council. One of the most important are the so-called anti-smog resolutions adopted by the provincial assemblies based on the legal basis of Article 96, the Environmental Protection Law Act of 27.04.2001 [6]. Their goal is to significantly improve air quality in urban areas. In the context of smog prevention, recommendations on the type of heating equipment allowed and the types of prohibited fuels are also included in local plans. The analysed local plans included methods of heat supply. The supply of heat should be based on the use of district heating networks, if available. In the absence of these, it should be possible to supply heat from local heat sources that operate, for example, using gaseous or liquid fuels. In turn, the use of electricity or unconventional heat sources for heating purposes is a kind of proverbial milestone towards improving the climate. It is important that the heating of buildings does not cause excessive gas or dust emissions to the atmosphere. To sum up, local spatial development plans recommend the use of heating equipment with high efficiency and a low pollution generation.

When analysing the so-called agricultural and forestry plans, where plan areas were designated as undeveloped areas of agricultural and forestry character, the main provision used in the general arrangements of the plan included the obligation to maximally preserve the agricultural and forestry production space. The areas in the form of existing mid-field watercourses and drainage ditches are protected. For many agricultural areas, a complete ban on the location of buildings, sometimes even including buildings related to agricultural production, is foreseen. The same applies to woodlands and afforestation. Moreover, in a situation where it is possible to construct buildings and carry out development connected with agricultural industry (in particular in terms of collecting and storing plant protection agents, mineral and organic fertilizers), it is required to apply solutions preventing penetration of pollutants into water, soil and ground, in accordance with separate provisions.

A special place in the local plans is occupied by the arrangements for the areas intended for water facilities in the form of flood embankments. They are located in the vicinity of river beds as part of flood prevention. In the case of such functions, in the first place, there is a ban on any buildings, cultivation of land, as well as planting trees and bushes on the dikes themselves and within a distance of less than $3 \mathrm{~m}$ from the foot of the dyke on landside. It is also prohibited to dig wells, ponds, pits and ditches within $50 \mathrm{~m}$ of the foot of the dike, also on the landside (Figure 3). 


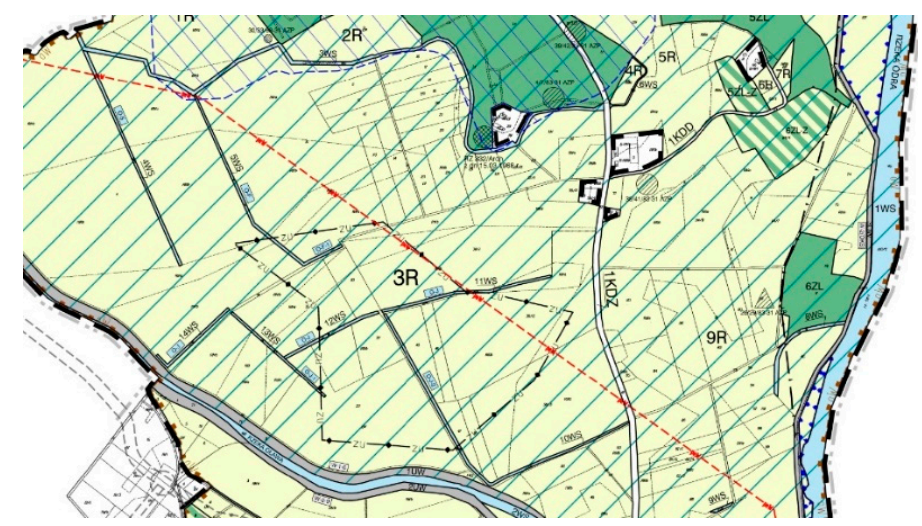

Figure 3. A fragment of the planning study supporting agricultural and forest functions, with the prohibition of building the presented areas, taking into account the natural routes of drainage ditches and flood embankments from the river bed. Source: [27].

When it comes to planning new buildings in areas of high flood risk, the planning arrangements used in the analysed local plans were somewhat differentiated.

At times, provisions made it compulsory to prohibit newly designed development altogether. In other cases, on the other hand, they allowed new development, e.g., singlefamily housing, but only in an area where the flood depth was less than or equal to $0.5 \mathrm{~m}$ (Figure 4).

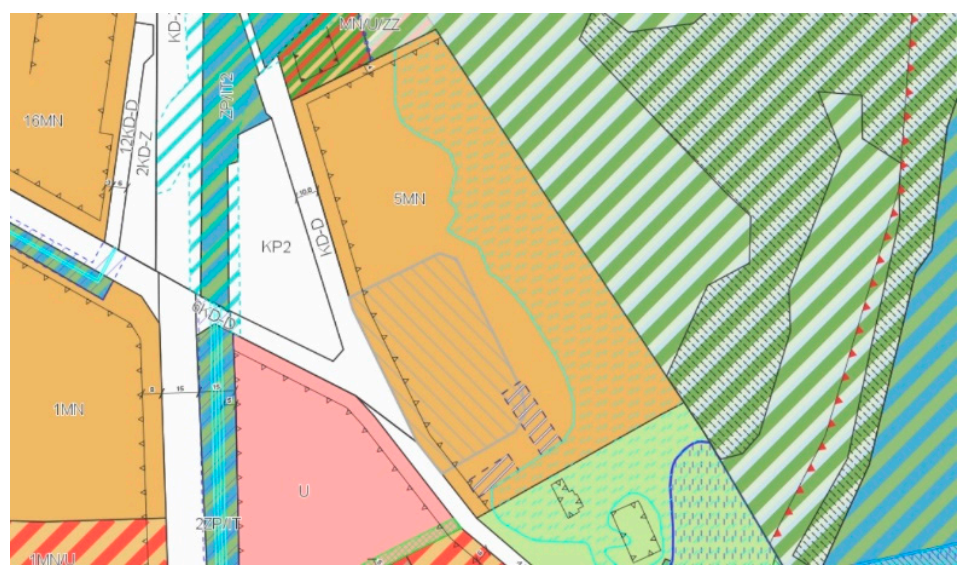

Figure 4. Image of the local plan in some areas of particular flood risk. Source: [32].

For areas at particular risk of flooding, according to some local plans, other strict conditions must also be met in the form of specific restrictions, e.g., allowing only buildings without basements, or the need to raise the floor level of the building by at least $0.5 \mathrm{~m}$ above the floodwater level, etc.

With regard to electricity supply using renewable energy sources, local plans in areas of intensive settlement usually allow for equipment with a capacity of up to $100 \mathrm{~kW}$ (photovoltaics) (Figure 5a). Special protection zone boundaries, within which a number of bans and orders were in force, were set for the location of renewable energy generation facilities with a capacity exceeding $100 \mathrm{~kW}$ (wind farms) (Figure 5b). 


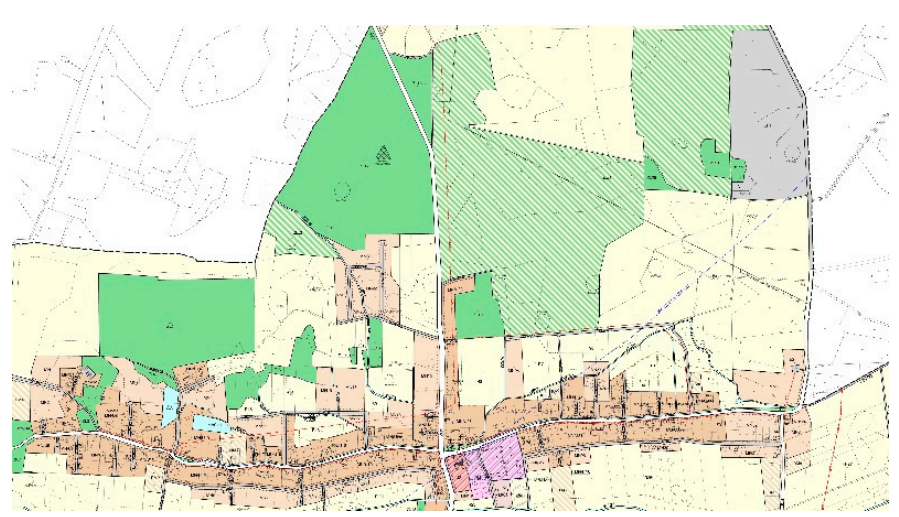

(a)

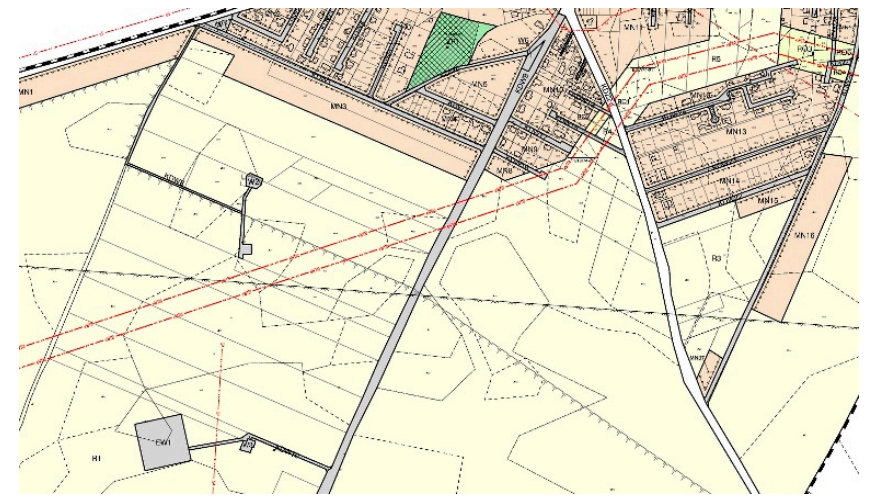

(b)

Figure 5. Personnel from the approved local development plan in the Lower Silesia Province, in rural areas, indicating the location of the areas of energy production from renewable sources: (a) whose power does not exceed $100 \mathrm{~kW}-$ photovoltaics (EF1); (b) with a capacity exceeding $100 \mathrm{~kW}$-wind farms (EW1) with a protection zone. Source: [27].

\section{Research Results}

Table 2 below summarises quantitative and qualitative data illustrating the provisions, indications and restrictions applied in the examined local spatial development plans, which may be important in preventing the negative effects of climate change. In the course of the analysis of the planning provisions of selected studies, the applied provisions relating to climatic issues were classified into the following groups: 1-urban indicators (min. biologically active area and max. built-up area (in \%)); 2-specific determinations of the area functions; 3-regulating heating issues; 4-rainwater management; 5-technical infrastructure systems; 6 - protection of green areas; 7 - ban on building development (e.g., in agricultural and forest areas). Finally, 17 plans covering urban areas and 25 plans in rural areas were examined. All analysed local plans were valid studies (as of May 2021), and the date of enacting the local laws was in the range of 2006-2021.

Based on the summary table presented above, the conducted analyses showed that all the plans subject to the study contained arrangements that determined the urban coefficients in the form of the minimum share of biologically active areas $\left(\mathrm{P}_{\mathrm{bcz}}\right)$, as well as the maximum built-up area factor $\left(\mathrm{P}_{\mathrm{z}}\right)$-column no. 1 . In two cases out of the forty-two, the biologically active factor was set at $0 \%$ (local plans no. 11 and 16), but only in one case this was due to the situation where the built-up area equaled the plot area, a provision justified in the specific example.

Column no. 2 notes the application of certain specific provisions for the functions of the area applied in several local plans, as well as specific provisions that specified these defined functions (in 17 out of 42 cases). Among the most popular examples, there were the permits for photovoltaics to be located in designated zones on agricultural land, but also on functional areas indicated (EF) in the plan (local plans no. 10 and 29). In one case (local plan no. 9), specific locations of renewable energy sources with a capacity exceeding $100 \mathrm{~kW}$ (wind farms-EW) were determined, together with the designation of their protection zones. 


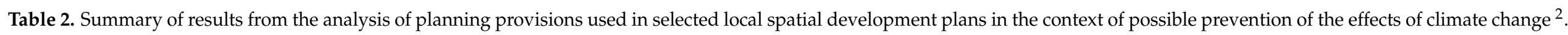

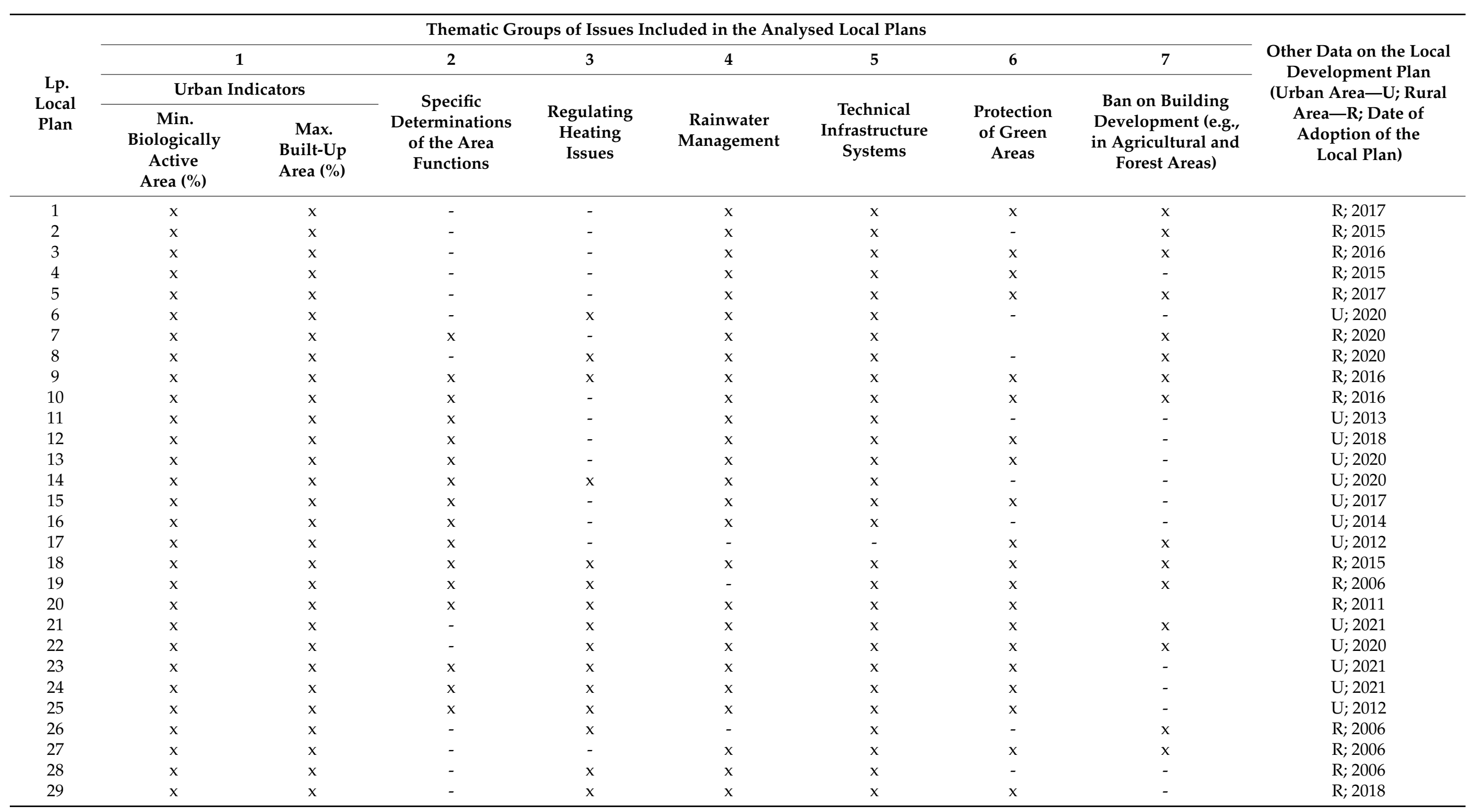


Table 2. Cont.

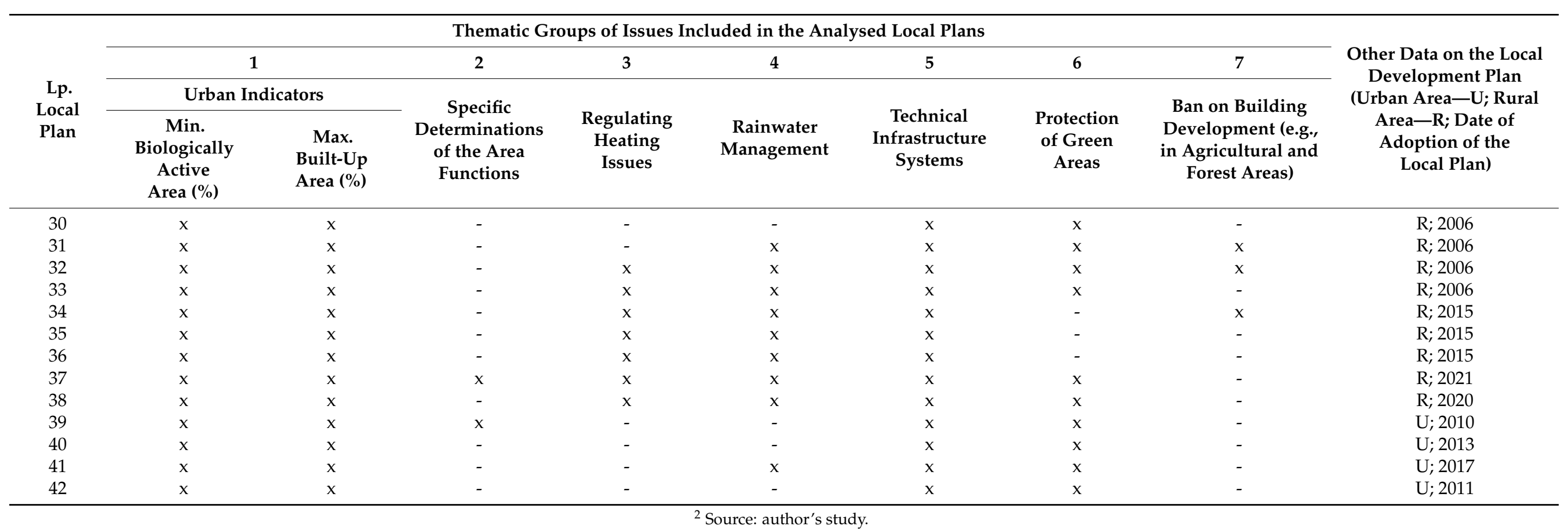


Another specific arrangement of some of the plans was that investment areas were supplemented with separate green zones, which were given specific development rules (e.g., a line of trees, an acreage of tall greenery, plantings of insulating greenery high in terms of burdensome functions). One of the local plans (local plan no. 18) prohibited backfilling ponds and drainless depressions of the land, and at the same time required the preservation of the existing watercourses and ditches, as well as the continuity of the existing drainage system. Local plans with special conditions, characterized by flood risk zones, recommended the construction of embankments on agricultural land to protect residential development from flooding. Where there were existing dykes in the planning areas, it was agreed that these dykes, but also any watercourses and drainage ditches, should be absolutely protected.

Heating (column no. 3) was provided for in the analysed plans in most cases by a regulation requiring the use of highly efficient heating devices with low pollutant emissions, less often, however, with a specific reference, e.g., to the use of ecological fuels as in the local development plan no. 8.

With a few exceptions, most of the examined plans established the principles of rainwater management mainly on the basis of the so-called small-scale retention principle (column No. 4). Small-scale retention is essential because, when combined with large-scale retention investments, it can counter droughts and floods, which are among the most dangerous effects of current climate change.

All analysed local plans provided arrangements for technical infrastructure systems in the form of underground utilities (column no. 5).

Plan areas that designated some areas as green spaces, overwhelmingly mentioned the requirement to protect these areas (column no. 6).

As almost half of the analysed plans to some extent included agricultural, forest or broadly understood green areas (managed and unmanaged) within their boundaries, provisions limiting the possibility of development were applied in order to maintain or extend their non-investment character, which certainly prevented the uncontrolled spread of construction (column no. 7).

\section{Conclusions}

Spatial planning faces an exceptionally difficult scenario for the future in the present reality. Industrialization, technological progression and unrestricted urbanization have led indirectly to dramatic climate change on a global scale. Heads of State and Governments decided in 2007 to reduce greenhouse gas emissions by $50 \%$ by 2050 , compared to 1990 levels [33]. This enormous challenge was posed to states as part of comprehensive international agreements.

Adaptation activities to the occurring climate change include various planning interventions in Poland, which are implemented at the national, regional and local level. An unquestionable challenge for spatial planning in general is the possibility of defining such planning provisions that would guarantee the application of pro-ecological spatial solutions. Moreover, one of the most important recommendations for legislative changes is the transformation of planning systems from passive to proactive [34].

This article focused on the opportunities offered by local spatial planning arrangements to prevent the possible consequences of climate change. An increase in the average annual air temperature, as well as changes in the average annual precipitation, strong winds with weather anomalies in the form of tornados, floods, sudden and heavy snowfall, or long-lasting droughts leading to dangerous fires, threaten humanity, generating enormous losses and costs.

Following analyses of the planning provisions applied in selected local spatial development plans for areas located in the Lower Silesia and Greater Poland regions, certain practices of applying varied arrangements were noticed, which were aimed to minimize the occurrence of negative effects of the extensive urbanisation process on the environment. In the context of the negative consequences that the progressing climate change was causing, 
the research showed that instructions tended to be both general and site-specific. The most important message resulting from the analysed planning studies was the absolute requirement to manage space in accordance with the principles of sustainable development. Restricting the location of projects that may have a significant impact on the environment is required especially in the reach of residential zones. Subsequent recommendations include the use of such urban indicators that allow for differentiating the height of buildings adequately to the location and adjacent space (high buildings in the city centre, low buildings on the outskirts of the cities, while maintaining an appropriate distance between buildings in both cases). Ensuring a high ratio of biologically active areas in relation to the area of the development plot (also with the use of technical treatments in the form of, e.g., green roofs or facades), as well as planting greenery in open spaces to loosen up the development are essential for the urban climate.

As part of pro-environmental measures that contribute to counteracting the effects of climate change, the findings from the reviewed local plans included the need to save energy and obtain it from alternative sources. It was recommended to develop sustainable transport, the use of highly efficient and low-emission heating equipment, all in the context of reducing the effect of the so-called 'urban heat island'. The shaping of space with the use of appropriate urban planning tools took into account the local air circulation, for example, by moving the building lines away from the borders of watercourses, rivers or ecological courses, and by recommending low greenery in such areas and contrasting the adjacent surface coverage.

In the context of urban sensitivity studies, adaptation abilities should be taken into account, including the characteristics of the progressive changes for the present and for the future [35]. This principle indicates that the decisions that are taken now will undoubtedly have an impact on the near, but also distant future.

Adaptation plans alone cannot change the course of events, especially since scientific theories also mention the human-made causes of climate change. The Milankovitch theory states that, due to the shape of the Earth's orbit, including the position of the Earth's axis relative to this orbit and relative to the Sun, the Earth has had different cycles in its history. This changing position affects the different levels of energy reaching our planet. In extreme moments, this level may deviate from the norm by up to 20-30 percent. It should be borne in mind that the observed climate change is an extremely long-term process and, ultimately, difficult to predict, despite current extensive climate research. Moreover, many variables influence the effects of climate change.

On the basis of the conducted research and keeping in mind the progressing climate change, a fundamental question arises: are the planning provisions proposed in Poland's local spatial development plans sufficient to counteract the effects of the progressing climate change? To fully answer this question, additional research would need to be conducted. Undoubtedly, however, the arrangements used in the local plans under review were in themselves potentially of great value to the developed spaces. The planning provisions cited in this article indicated an undoubtedly interdisciplinary approach of these plans to the shaping of space in Poland and the fact that they take into account the protection of such spaces, as well as natural and environmental elements which function independently and accompany it, and whose degradation has an impact on climate change. It is important to be aware that the opportunity for contemporary spaces lies primarily in developing harmony between man-made and natural systems, directing both towards a development that has the potential to build both social and environmental capital [31].

In fact, the research conducted so far has undoubtedly highlighted a significant problem in the planning system in Poland at the commune level. The planning provisions used in local spatial development plans are only able to prevent progressing climate change to a small extent. The limitations are largely the result of the completely unclear position of the Polish law regarding the necessity and possibility of applying specific binding planning provisions that could regulate a climate policy at the level of local planning. In addition, there are no appropriate tools to verify whether, in the course of the implementation of the 
local plan, arrangements aimed at preventing the effects of climate change have been taken into account, and then implemented. Many of them are only so-called recommendations, not requirements. Moreover, the pro-climatic arrangements in the development of local spatial development plans are definitely immeasurable. Spatial planning focused on the needs of contemporary spaces that struggle with climate change should be carried out in an integrated manner, without systemic and hierarchical divisions. Only multi-sectoral action can prevent or mitigate the effects of climate change [36].

Funding: This research received no external funding.

Institutional Review Board Statement: Not applicable.

Informed Consent Statement: Not applicable.

Data Availability Statement: Not applicable.

Conflicts of Interest: The author declares no conflict of interest.

\section{References}

1. Legutko-Kobus, P.; Rzeńca, A.; Skubała, P.; Sobol, A. Miasta i ich Mieszkańcy w Obliczu Wyzwań Adaptacji do Zmian Klimatu; Polish Academy of Sciences: Warsaw, Poland, 2020; p. 9. ISBN 978-83-63305-92-5.

2. Kyoto Protocol Reference Manual on Accounting of Emissions and Assigned Amount. Available online: https://unfccc.int/ resource/docs/publications/08_unfccc_kp_ref_manual.pdf (accessed on 4 September 2021).

3. European Commission. Communication from the Commission to the European Parliament, the Council, the European Economic and Social Committee and the Committee of the Regions. An EU Strategy on adaptation to climate change. Available online: https:/ / ec.europa.eu/transparency/documents-register/detail?ref=SWD(2013)134\&lang=en (accessed on 6 November 2021).

4. Godlewska, J.; Sidorczuk-Pietraszko, E. Analiza Rozwiazań Wprowadzanych w Innych Państwach Europejskich w Zakresie Strategii, Narzędzi Prawnych i Ekonomicznych Pozwalajacych na Przygotowanie Gospodarki i Społeczeństwa do Zmian Klimatu i Przystosowanie do Tych Zmian; Instytut Ochrony Środowiska-Państwowy Instytut Badawczy: Warsaw, Poland, 2020.

5. Marszałek Sejmu. Ustawa z Dnia 27 marca 2003 r. o Planowaniu i Zagospodarowaniu Przestrzennym, Unified text: Dz. U. z 2021 r. poz. 741, z późn. zm.; Marszałek Sejmu: Warsaw, Poland, 2003.

6. Marszałek Sejmu. Ustawa z Dnia 27 kwietnia 2001 r. Prawo Ochrony Środowiska, Unified text: Dz. U. z 2020 r. poz. 1219, z późn. zm.; Marszałek Sejmu: Warsaw, Poland, 2001.

7. Szulczewska, B. Ekologia Krajobrazu Miasta: Teoria i Praktyka. Problemy Ekologii Krajobrazu 2014, 21, 69.

8. Richling, A. Ekologia krajobrazu—Nauka czy pole badawcze? In Problemy Ekologii Krajobrazu; Chmielewski, T.J., Ed.; Volume 21: Struktura i funkcjonowanie systemów krajobrazowych: Meta-analizy, modele, teorie i ich zastosowania; Polska Asocjacja Ekologii Krajobrazu: Lublin, Poland,, 2008; p. 16.

9. Jiang, Y.; Hou, L.; Shi, T.; Gui, O. A Review of Urban Planning Research for Climate Change. Sustainability 2017, 9, 2224. [CrossRef]

10. Lenart, W. Miasto w zgodzie z klimatem. In Miasto Idealne-Miasto Zrównoważone. Planowanie Przestrzenne Terenów Zurbanizowanych i Jego Wptyw na Ograniczenie Skutków Zmian Klimatu; Kalinowska, A., Ed.; Uniwersytet Warszawski: Warsaw, Poland, 2015; p. 23. ISBN 978-83-917679-6-2.

11. Howard, L. The Climate of London, Tom 1; W. Philips: London, UK, 1818; pp. 1-204.

12. Fortuniak, K. Badania klimatu miast w Polsce. Przeglad Geofiz. 2019, 1-2, 73-106.

13. Urban Heat Islands (UHIs). Available online: https:/ / www.urbanheatislands.com/ (accessed on 6 November 2021).

14. Bokwa, A. Rozwój badań nad klimatem lokalnym Krakowa. Acta Geogr. Lodz. 2019, 108, 7-20.

15. Shen, Z.; Shi1, J.; Tan, J.; Yang, H. The Migration of the Warming Center and Urban Heat Island Effect in Shanghai During Urbanization. Front. Earth Sci. 2020, 8, 1-12. [CrossRef]

16. Gawuc, L.; Jefimow, M.; Szymankiewicz, K.; Kuchcik, M.; Sattari, A.; Struzewska, J. Statistical Modeling of Urban Heat Is-land Intensity in Warsaw, Poland Using Simultaneous Air and Surface Temperature Observations. IEEE J. Sel. Top. Appl. Earth Obs. Remote Sens. 2020, 13, 2716-2728. [CrossRef]

17. Klimada 2.0. Adaptation to Climate Change. Available online: https://klimada2.ios.gov.pl/en/ (accessed on 8 November 2021).

18. Chojnacka-Ożga, L.; Lorenc, H. (Eds.) Wspótczesne Problemy Klimatu Polski; Instytut Meteorologii i Gospodarki Wodnej Państwowy Instytut Badawczy: Warsaw, Poland, 2019; ISBN 978-83-64979-33-0.

19. Kundzewicz, Z.W.; Hov, Ø.; Okruszko, T. Zmiany Klimatu i Ich Wptyw na Wybrane Sektory w Polsce; Narodowe Centrum Badań i Rozwoju: Poznań, Poland, 2017; pp. 26-27. ISBN 978-83-8104-753-7.

20. Wamsler, C.; Wickenberg, B.; Hanson, H.; Alkan Olsson, J.; Stålhammar, S.; Björn, H.; Falck, H.; Gerell, D.; Oskarsson, T.; Simonsson, E.; et al. Environmental and climate policy integration: Targeted strategies for overcoming barriers to nature-based solutions and climate change adaptation. J. Clean. Prod. 2019, 247, 119154. [CrossRef]

21. Klimada. Adaptation to Climate Change. Available online: http://klimada.mos.gov.pl/adaptacja-do-zmian-klimatu/ (accessed on 14 April 2021). 
22. Ministerstwo Infrastruktury. Rozporzadzenie Ministra Infrastruktury z Dnia 26 Sierpnia 2003 r. w Sprawie Wymaganego Zakresu Projektu Miejscowego Planu Zagospodarowania Przestrzennego, Legal text announced: Dz.U. 2003 nr 164 poz. 1587; Ministerstwo Infrastruktury: Warsaw, Poland, 2003.

23. Szmigiel-Rawska, K. Mechanizmy Polityki Klimatycznej Polskich Samorząów; Studia Regionalne i Lokalne Nr 1(67): Warsaw, Poland, 2017; p. 53. ISSN 1509-4995.

24. Billewicz, K. Efektywność energetyczna budynków a miejskie wyspy ciepła. Energetyka 2017, 1, 32-36.

25. Halama, A. Polityka Przestrzenna na Terenach Zalewowych w Matych Miastach, Studia Ekonomiczne t. 144; Uniwersytet Ekonomiczny w Katowicach: Katowice, Poland, 2014; pp. 311-322.

26. ISOK. Available online: https://imgw.isok.gov.pl/imap_imgw/ (accessed on 23 July 2021).

27. Official Journal of the Lower Silesian Voivodeship. Available online: https:/ / edzienniki.duw.pl/actbymonths (accessed on 23 May 2021).

28. Wrocław Spatial Information System. Local Plans. Available online: http://wrosystem.um.wroc.pl/beta_4/webdisk/215939/103 5ru08.pdf (accessed on 23 April 2021).

29. Reinwald, F.; Brandenburg Ch Gabor, A.; Hinterkörner, P.; Kainz, A.; Kraus, F.; Ring, Z.; Scharf, B.; Tötzer, T.; Damyanovic, D. Multi-Level Toolset for Steering Urban Green Infrastructure to Support the Development of Climate-Proofed Cities. Sustainability 2021, 13, 12111. [CrossRef]

30. Andrzejewska, A.K. The transformation of the communication infrastructure in relation to spatial and landscape changes of cities based on the example of Wroclaw. In Proceedings of the W: VI International Conference of Science and Technology INFRAEKO 2018 Modern Cities: Infrastructure and Environment, Krakow, Poland, 7-8 June 2018.

31. Rose, J.F.P. Dobrze Nastrojone Miasto; Wyd. Karakter: Kraków, Poland, 2019; p. 414. ISBN 978-83-66147-00-3.

32. Official Journal of the Greater Poland Voivodeship. Available online: http:/ / edziennik.poznan.uw.gov.pl/actbymonths (accessed on 24 April 2021).

33. Green Paper from the Commission to the Council, the European Parliament, the European Economic and Social Committee and the Committee of the Regions-Adapting to Climate Change in Europe-Options for EU action \{SEC(2007) 849\}. Available online: https: / / eur-lex.europa.eu/legal-content/PL/TXT/?uri=celex:52007DC0354 (accessed on 3 July 2021).

34. Hurlimann, A.C.; March, A.P. The role of spatial planning in adapting to climate change. Wiley Interdiscip. Rev. Clim. Chang. 2012, 3, 379-488. [CrossRef]

35. Kassenberg, A.; Szymalski, W.; Świerkula, E. Poradnik Adaptacji Miasta do Zmiany Klimatu; Wyd. Instytut na rzecz Ekorozwoju: Warsaw, Poland, 2019; p. 34.

36. Juschten, M.; Reinwald, F.; Weichselbaumer, R.; Jiricka-Pürrer, A. Developing an Integrative Theoretical Framework for Climate Proofing Spatial Planning across Sectors, Policy Levels, and Planning Areas. Land 2021, 10, 772. [CrossRef] 